\title{
Article \\ Spatio-Temporal Distribution of Cell Wall Components in the Placentas, Ovules and Female Gametophytes of Utricularia during Pollination
}

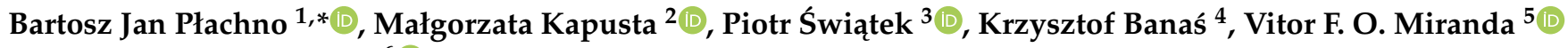 \\ and Anna Bogucka-Kocka ${ }^{6}$ (i)
}

1 Department of Plant Cytology and Embryology, Faculty of Biology, Institute of Botany, Jagiellonian University in Kraków, 9 Gronostajowa St., 30-387 Kraków, Poland

2 Department of Plant Cytology and Embryology, Faculty of Biology, University of Gdańsk, 59 Wita Stwosza St., 80-308 Gdańsk, Poland; malgorzata.kapusta@ug.edu.pl

3 Faculty of Natural Sciences, Biotechnology and Environmental Protection, Institute of Biology, University of Silesia in Katowice, 9 Bankowa St., 40-007 Katowice, Poland; piotr.swiatek@us.edu.pl

4 Department of Plant Ecology, Faculty of Biology, University of Gdańsk, 59 Wita Stwosza St., 80-308 Gdańsk, Poland; k.banas@ug.edu.pl

5 Laboratory of Plant Systematics, School of Agricultural and Veterinarian Sciences, São Paulo State University (Unesp), Jaboticabal CEP 14884-900, SP, Brazil; vitor.miranda@unesp.br

6 Chair and Department of Biology and Genetics, Medical University of Lublin, 20-093 Lublin, Poland; anna.kocka@umlub.pl

* Correspondence: bartosz.plachno@uj.edu.pl

check for updates

Citation: Płachno, B.J.; Kapusta, M.; Świątek, P.; Banaś, K.; Miranda, V.F.O.; Bogucka-Kocka, A. Spatio-Temporal Distribution of Cell Wall Components in the Placentas, Ovules and Female Gametophytes of Utricularia during Pollination. Int. J. Mol. Sci. 2021, 22, 5622. https:// doi.org/10.3390/ijms22115622

Academic Editor: Ryszard Lobinski

Received: 3 April 2021

Accepted: 23 May 2021

Published: 25 May 2021

Publisher's Note: MDPI stays neutral with regard to jurisdictional claims in published maps and institutional affiliations.

Copyright: (c) 2021 by the authors. Licensee MDPI, Basel, Switzerland. This article is an open access article distributed under the terms and conditions of the Creative Commons Attribution (CC BY) license (https:/ / creativecommons.org/licenses/by/ $4.0 /)$.

\begin{abstract}
In most angiosperms, the female gametophyte is hidden in the mother tissues and the pollen tube enters the ovule via a micropylar canal. The mother tissues play an essential role in the pollen tube guidance. However, in Utricularia, the female gametophyte surpasses the entire micropylar canal and extends beyond the limit of the integument. The female gametophyte then invades the placenta and a part of the central cell has direct contact with the ovary chamber. To date, information about the role of the placenta and integument in pollen tube guidance in Utricularia, which have extra-ovular female gametophytes, has been lacking. The aim of this study was to evaluate the role of the placenta, central cell and integument in pollen tube pollen tube guidance in Utricularia nelumbifolia Gardner and Utricularia humboldtii R.H. Schomb. by studying the production of arabinogalactan proteins. It was also determined whether the production of the arabinogalactan proteins is dependent on pollination in Utricularia. In both of the examined species, arabinogalactan proteins (AGPs) were observed in the placenta (epidermis and nutritive tissue), ovule (integument, chalaza), and female gametophyte of both pollinated and unpollinated flowers, which means that the production of AGPs is independent of pollination; however, the production of some AGPs was lower after fertilization. There were some differences in the production of AGPs between the examined species. The occurrence of AGPs in the placental epidermis and nutritive tissue suggests that they function as an obturator. The production of some AGPs in the ovular tissues (nucellus, integument) was independent of the presence of a mature embryo sac.
\end{abstract}

Keywords: arabinogalactan proteins; glycoproteins; AGPs; carnivorous plants; embryo sac; integument; Lentibulariaceae; ovule; pollen tube guidance

\section{Introduction}

In typical angiosperm plants, the female gametophyte (embryo sac) is hidden in the ovule and is covered by the nucellus and one or two integuments [1]. Angiosperm ovules are incredibly diverse in the terms of their size, the degree of ovule curvature, nucellus thickness, number of integuments and their thickness, the formation of the micropyle, the length of the funiculus, the degree of the vascularization of the ovule and the presence of 
structures such as an endothecium, hypostase and postament [2]. Sporophytic tissues not only protect the female gametophyte and transport nutrients to it, but also guide the male gametophyte to the female gametophyte e.g., [3-7]. The great success of angiosperms is associated with the diverse structure of their styles and ovules and the sites of the pollen tube pathway [8-11]. During pollen tube growth, there is a dialogue between the male gametophytes and sporophytic tissues [12], but there is also competition between the pollen tubes, i.e., gametophytic competition $[9,13]$. In most cases, the pollen tube meets the female gametophyte only when it grows into the micropylar canal and the first elements of the female gametophyte that it meets are the synergids. However, there are some exceptions. In Plumbago and Plumbagella in which synergids are absent, the egg cell takes over the functions of a synergid [14]. Another evolutionary experiment is an extra-ovular female gametophyte, which extends beyond the limit of the integument. These specific partially "naked" female gametophytes have evolved in the different lineages of angiosperms, such as: Santalales: Thesium; Gentianales: Galium; Cornales: Philadelphus; Lamiales: Torenia, Lindernia and Utricularia [15-18]. Unfortunately, apart from Torenia and Lindernia, detailed knowledge about the interactions of an extra-ovular female gametophyte with the sporophytic tissues and pollen tubes is quite limited. The model species is Torenia fournieri Linden ex E. Fourn. $[19,20]$, which has the extra-ovular egg apparatus and was used to prove that the synergids are responsible for attracting the pollen tubes in angiosperms [21-23]. In Torenia, the synergids produce small proteins (LUREs), which attract the pollen tubes [24]. However, the ovular arabinogalactan sugar chain (AMOR) is needed to make the pollen tubes fully competent for LURE peptides, and therefore the sporophytic tissues use arabinogalactan proteins to guide the gametophytic pollen tube [20,25].

Arabinogalactan proteins (AGPs) are important signaling molecules during cell-cell communication, which are spatio-temporally distributed in the plant generative organs e.g., [26-28] but have been also identified in vegetative organs (in mesophyll cell, epidermal cells, xylem, root cap cells, etc.) [29]. AGPs have been recorded in the styles, ovules and female gametophytes of various plant species. Their occurrence is connected with the specific stages of development, a specific tissue, organ and/or pollen tube growth e.g., $[7,28,30-33]$. In some species, the production of AGPs in ovules is triggered by pollen tube passage $[6,33,34]$, while in others, their production is independent of pollination [7].

However, there is still a lack of information about the AGPs in ovules of Utricularia. In some species of this genus, the central cell is hypertrophied at the micropylar pole and invades the placenta. Moreover, a part of the central cell has direct contact with the ovary chamber $[16,18,35]$. According to Khan [36], in Utricularia, the pollen tube meets the female gametophyte in the ovarian cavity (exogamous fertilization). Although the occurrences of AGPs in the ovules and female gametophytes have been extensively studied in porogamous species, only one study has addressed this in a plant with a different mode of pollen tube growth, the chalazogamous species Mangifera indica L. [37].

Therefore, the aim of this study was to evaluate the role of the placenta (the epidermis and the special "nutritive tissue" that is situated below the embryo sac [38]), the ovular tissues and hypertrophied central cell and the integument in pollen tube guidance in Utricularia nelumbifolia Gardner and Utricularia humboldtii R.H.Schomb. by studying the production of arabinogalactan proteins. It was also determined whether the arabinogalactan proteins in Utricularia are dependent on pollination.

\section{Results}

\subsection{Arabinogalactan Proteins in the Placenta and Ovules before Pollination}

In both species, there were mature embryo sacs in most of the ovules during anthesis (Figure $1 \mathrm{~A}-\mathrm{C}$ and Figure $2 \mathrm{~A}-\mathrm{C}$ ). Only some of the ovules did not contain a mature embryo sac (e.g., there was one nucleate embryo sac that had arrested in development). In Utricularia nelumbifolia and $U$. humboldtii, there was an intense accumulation of AGPs (labeled with JIM13) in the embryo sac, especially in the micropylar enlarged part of the central cell (Figure 2D-H). Moreover, these AGPs were also detected in the synergids and egg cell 
(Figure 2E-G). In U. humboldtii, there was an intense accumulation of AGPs (labeled with JIM13) in the chalaza cells and integument cells at the micropylar pole (Figure 2G). Only some of the placenta cells had these AGPs. These cells were located near the micropylar part of the embryo sac. There were no AGPs (labeled with JIM13) in the chalazal ovular cells in Utricularia nelumbifolia, although they did occur in a few of the integument cells that adhered to the embryo sac (Figure 2D). However, they only occurred in the placental epidermal cells that had contact with central cell (Figure 2E). Nucellus epidermis was persistent even in ovules in which the development of the embryo sac has been stopped (U. humboldtii). In those ovules, AGPs (labeled with JIM13) were detected in the nucellus, chalaza and integument (Figure 2I).
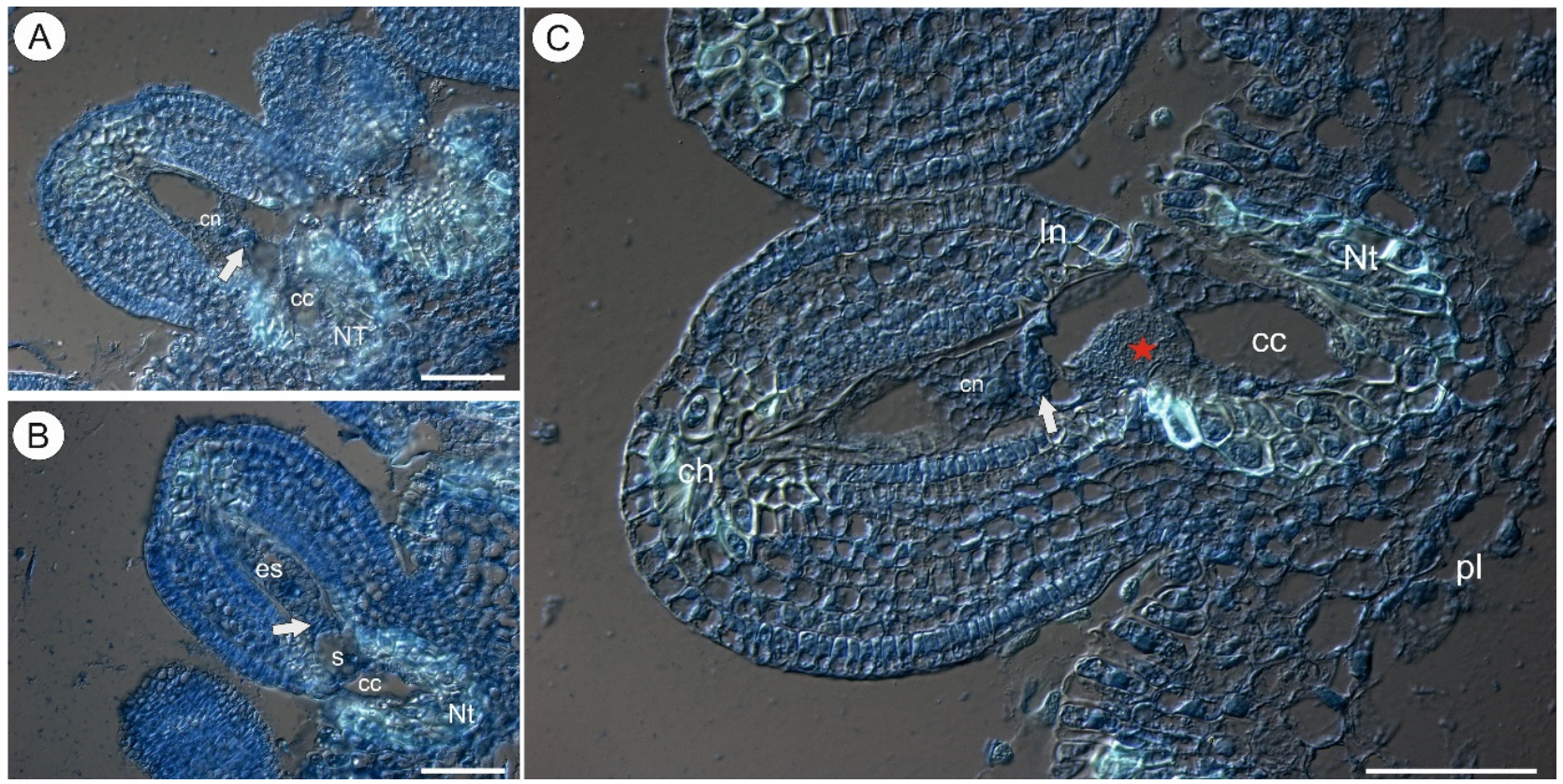

Figure 1. Histology of an ovule of Utricularia nelumbifolia; differential interference contrast (DIC) optics. Sections stained with DAPI (blue fluorescence) and DAB (decolorized aniline blue, white fluorescence). (A,B) Ovules before penetration by the pollen tubes. (C) Ovule after penetration by the pollen tube (red star). Note the egg cell (arrow), embryo sac (es), synergid (s), nucleus of the central cell (cn), hypertrophied part of the central cell (cc), placental nutritive tissue (Nt), integument (In), chalaza (ch), placenta (pl). Note callose occurrence (white fluorescence) in the cell walls of the placental nutritive tissue cells and chalaza cells. All bars $50 \mu \mathrm{m}$.

In Utricularia nelumbifolia, the JIM8-labeled epitopes were only detected in a single or a few cells of the endothelium. None of these AGPs were detected in the central cells of the embryo sacs (Figure 3A,B). In U. humboldtii, these AGPs occurred in some of the endothelial cells, chalazal cells and in the embryo sac (Figure 3C,D).

In Utricularia nelumbifolia, AGPs (labeled with JIM14) were detected in the integument cells that were located near the micropylar part of the embryo sac as well as in the placenta cells (nutritive tissue), however, only in some cases. These AGPs were also detected in of the embryo sacs in the egg apparatus and central cell (Figure 3E,F). In U. humboldtii, these AGPs occurred in the endothelial cells, chalazal cells and placental cells (epidermal cells and nutritive tissue near the embryo sac, Figure 3G,H). In U. nelumbifolia, AGPs (labeled with JIM14) were detected in the nucellus in the ovule in which embryo sac development had been arrested (Figure 4A). 


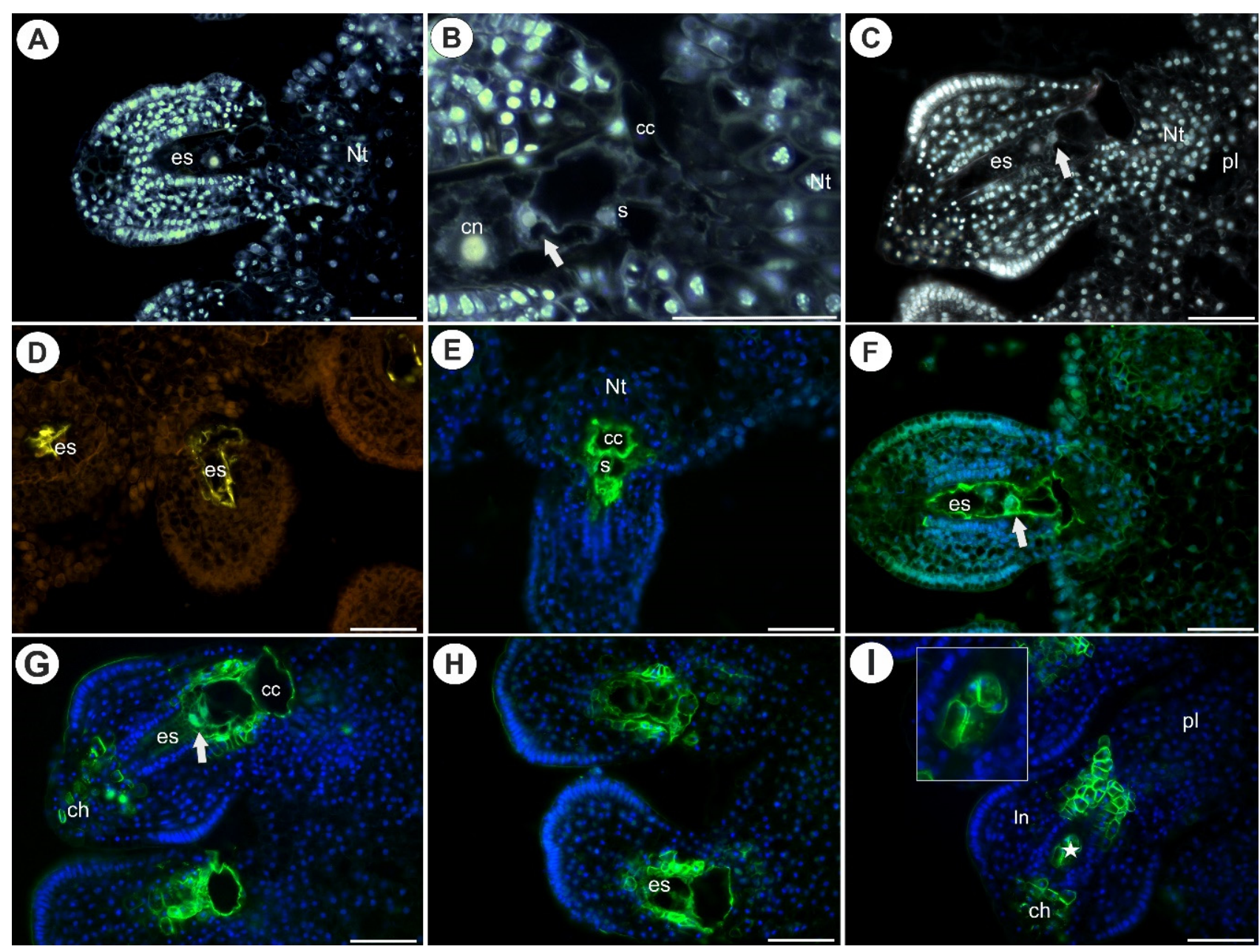

Figure 2. Histology and AGP (JIM13) detection in an ovule of Utricularia nelumbifolia and Utricularia humboldtii before pollination. (A) Section through the ovule and placenta of U. nelumbifolia (stained with DAPI, blue fluorescence); note the presence of a mature embryo sac (es), placental nutritive tissue (Nt). (B) U. nelumbifolia (stained with DAPI, blue fluorescence), higher magnification of the micropylar part of the ovule and embryo sac; note the egg cell (arrow), synergid (s), nucleus of the central cell (cn), hypertrophied part of the central cell (cc), placental nutritive tissue (Nt). (C) Section through the ovule and placenta of $U$. humboldtii (stained with DAPI, blue fluorescence); note the presence of a mature embryo sac (es), egg cell (arrow), placental nutritive tissue (Nt), placenta (pl). (D-F) Arabinogalactan protein (labeled with JIM13, green fluorescence) detected in U. nelumbifolia: embryo sac (es), egg cell (arrow), synergid (s), hypertrophied part of the central cell (cc), placental nutritive tissue (Nt); yellowish signal is autofluorescence. $(\mathbf{G}, \mathbf{H})$ Arabinogalactan protein (labeled with JIM13, green fluorescence) detected in U. humboldtii: embryo sac (es), egg cell (arrow), hypertrophied part of central cell (cc), placental nutritive tissue (Nt), chalaza (ch). (I) Arabinogalactan protein (labeled with JIM13, green fluorescence) detected in the ovule of $U$. humboldtii that did not contain a mature female gametophyte. Note the occurrence of AGPs in remaining nucellus epidermis (star, and framed part), integument (In), chalaza (ch), placenta (pl). All bars $50 \mu \mathrm{m}$. 


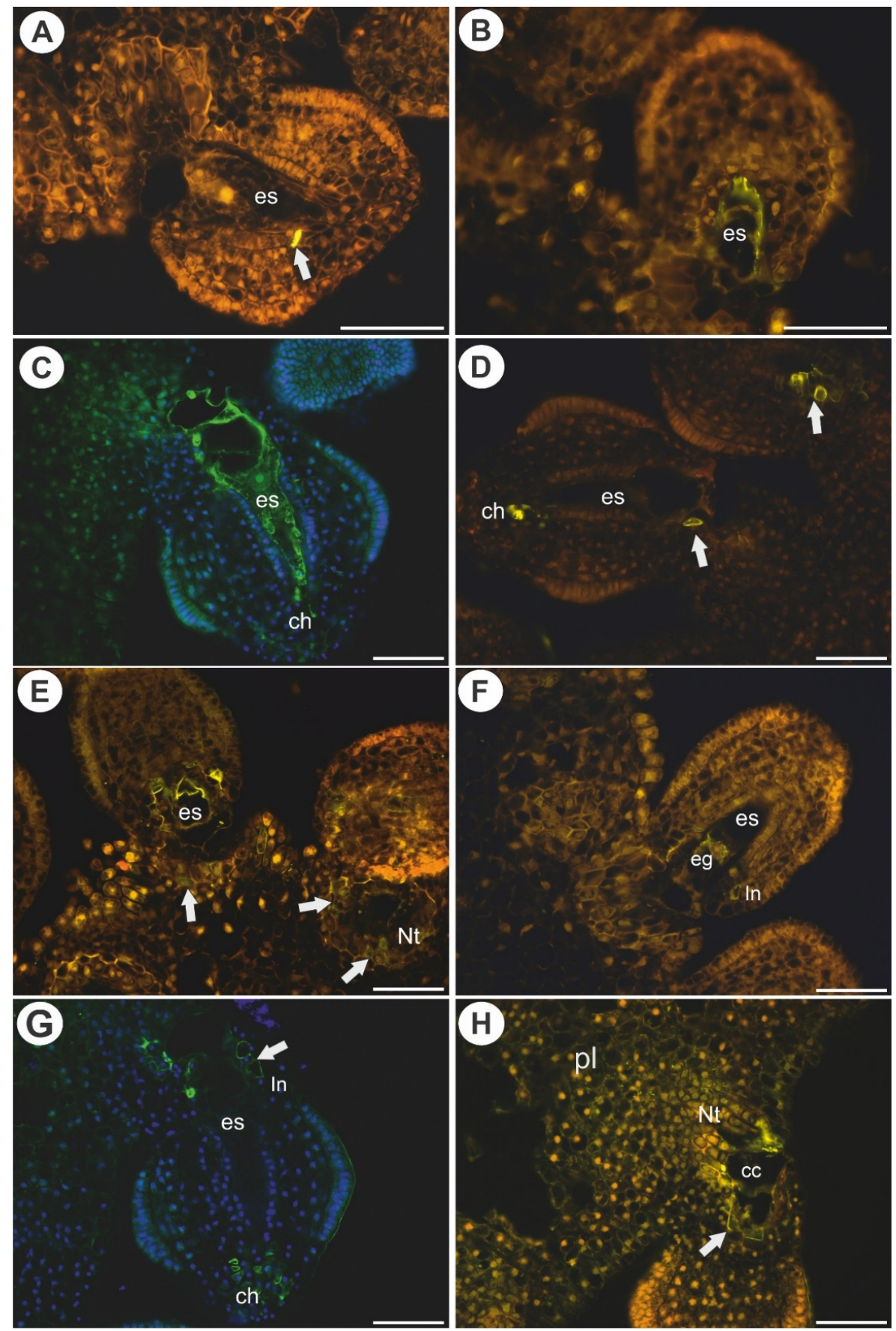

Figure 3. Arabinogalactan proteins (labeled with JIM8 and with JIM14, green fluorescence) detected in Utricularia nelumbifolia and Utricularia humboldtii before pollination. (A,B) Arabinogalactan protein (labeled with JIM8, green fluorescence) detected in U. nelumbifolia: embryo sac (es), positive signal in the integument cell (arrow); yellowish signal is autofluorescence. (C,D) Arabinogalactan protein (labeled with JIM8, green fluorescence) detected in U. humboldtii, embryo sac (es), chalaza (ch), note the positive signal in the integument cells (arrow); yellowish signal is autofluorescence. (E,F) Arabinogalactan protein (labeled with JIM14, green fluorescence) detected in U. nelumbifolia: embryo sac (es), positive signal in placenta nutritive tissue (Nt) cell (arrow), egg cell (eg), integument (In); yellowish signal is autofluorescence. $(\mathbf{G}, \mathbf{H})$ Arabinogalactan protein (labeled with JIM14, green fluorescence) detected in $U$. humboldtii; embryo sac (es), placenta (pl), nutritive tissue (Nt), integument (In), chalaza (ch), positive signal in the integument cells (arrow); yellowish signal is autofluorescence. All bars $50 \mu \mathrm{m}$. 

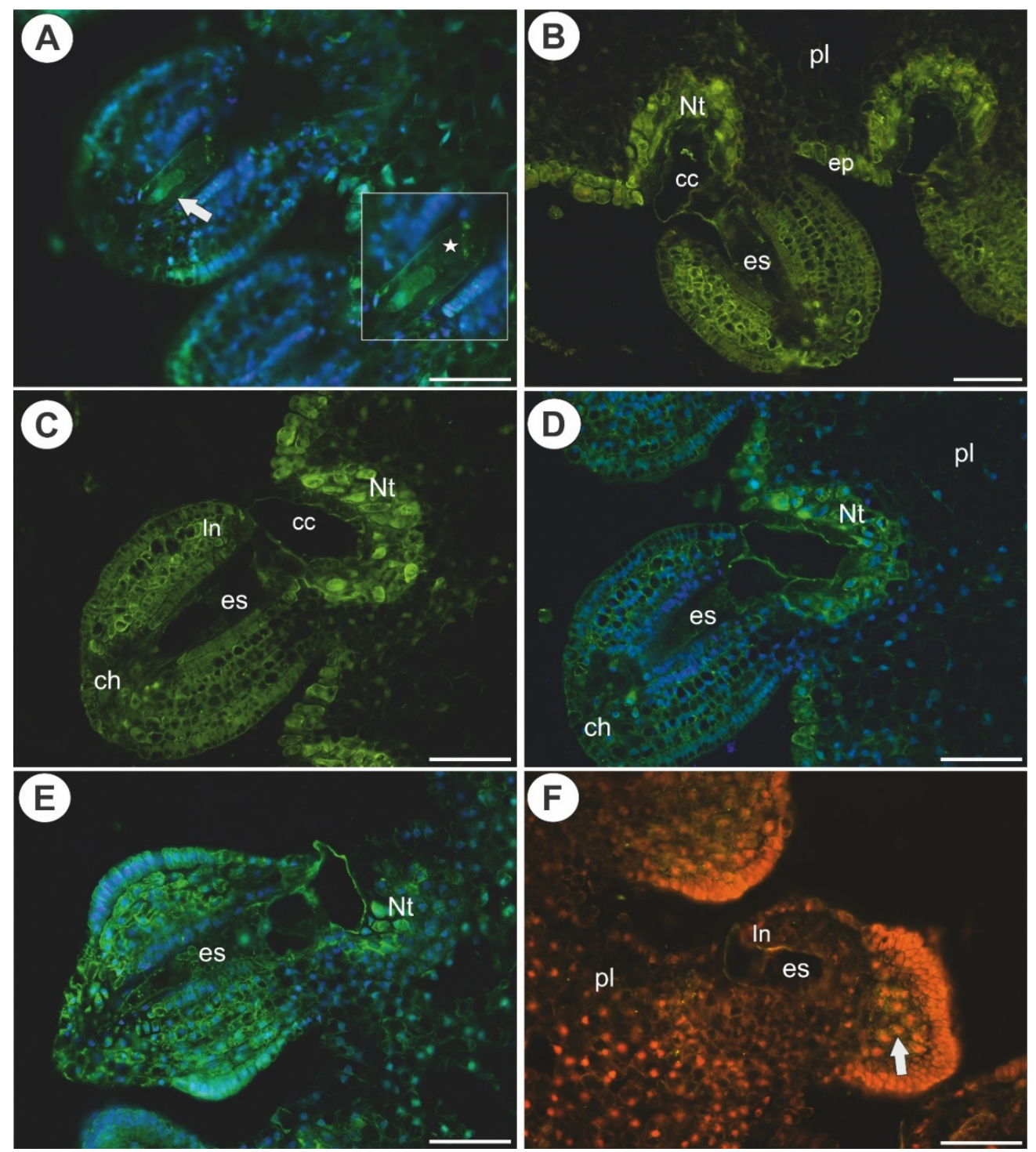

Figure 4. Arabinogalactan proteins (labeled with JIM14 and with LM2) detected in Utricularia nelumbifolia and Utricularia humboldtii before pollination. (A) Arabinogalactan protein (labeled with JIM14, green fluorescence) detected in the ovule of $U$. nelumbifolia that did not contain a mature female gametophyte (arrow). Note the occurrence of AGPs in remaining nucellus epidermis (star, framed part). (B-D) Arabinogalactan protein (labeled with LM2, green fluorescence) detected in U. nelumbifolia; note the strong positive signal in the nutritive tissue $(\mathrm{Nt})$ and epidermis of placenta (ep); embryo sac (es), chalaza (ch), hypertrophied part of central cell (cc), integument (In). (E,F) Arabinogalactan protein (labeled with LM2, green fluorescence) detected in U. humboldtii: embryo sac (es), pl (placenta), nutritive tissue (Nt), positive signal in ovule tissue (arrow); yellowish signal is autofluorescence. All bars $50 \mu \mathrm{m}$.

In Utricularia nelumbifolia and U. humboldtii, the AGP epitopes that are recognized by LM2 occurred in the parenchyma cells of the ovules, the cells at the chalaza and in the micropylar part of the embryo sac (Figure 4B-D). These AGPs were also detected in the placental nutritive tissue and epidermis of the placenta of Utricularia nelumbifolia (Figure 4E,F).

\subsection{Observation of Pollen Tube Growth}

The pollen grains were germinated at the sigma (Figure 5A). Pollen tubes grew on the papillae of the stigma (Figure $5 \mathrm{~B}$ ) and entered the stylar tissue. Next, they entered the stylar canal (Figure 5C). At the bottom of the stylar canal, the pollen tubes formed a bundle 
that finally entered the ovarian cavity and reached the placenta (Figure 5D). The ovules that were located below ovarian stylar canal were covered by pollen tubes (Figure 5E). Then, pollen tubes grew on the surface of the placenta to reach the embryo sacs of ovules (Figure 5F). Six and nine hours after pollination there were still some nonfertilized ovules. The pollen tubes penetrated the ovules that were located at the top of the placenta first.
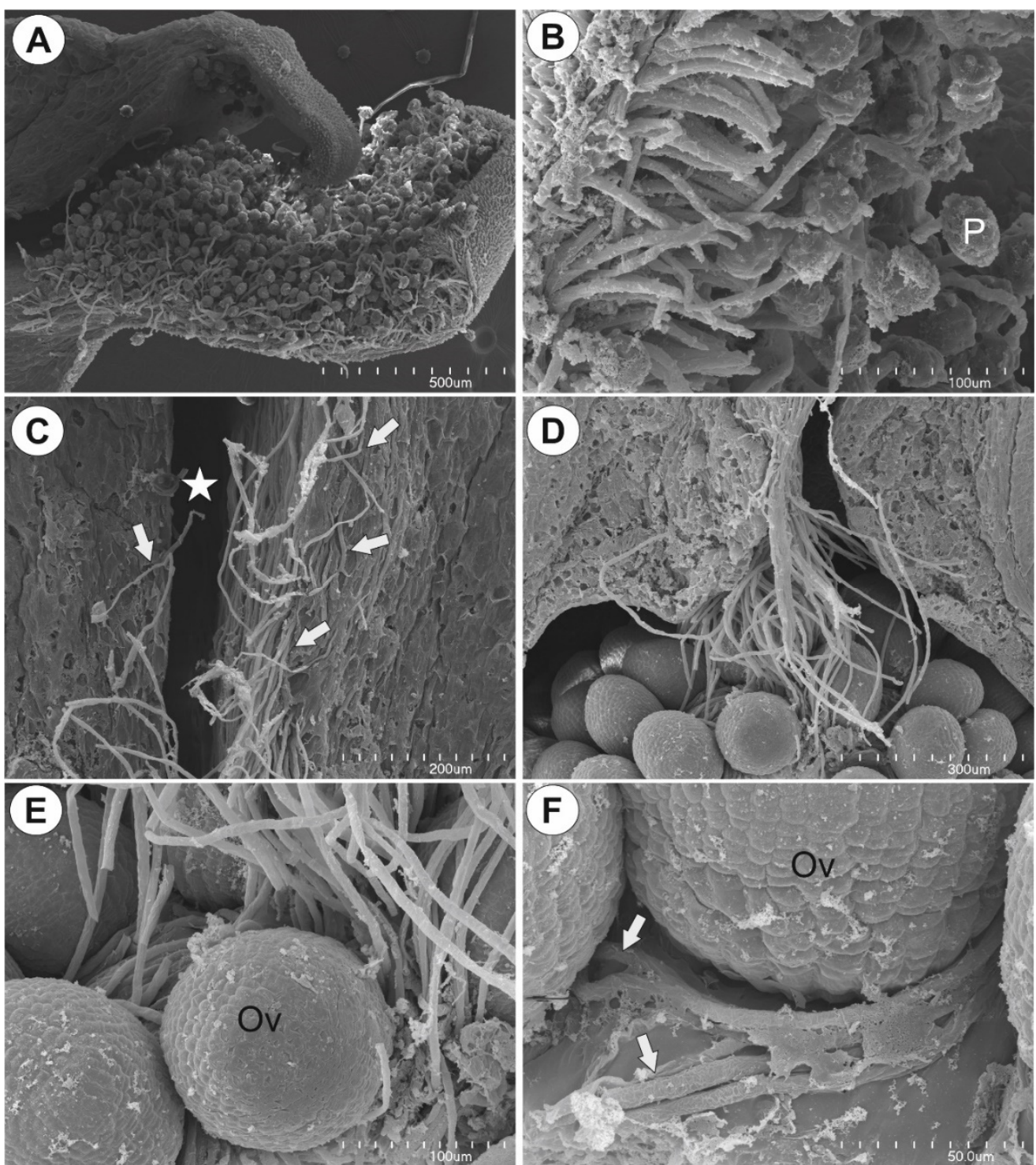

Figure 5. Pollen tube growth in Utricularia nelumbifolia. (A,B) Pollen grains with pollen tubes on the stigma surface; pollen grain (P). (C) Pollen tubes (arrows) in the stylar; stylar canal (star). (D) Bundle of pollen tubes that entered the ovarian cavity. (E) Pollen tubes on the ovules (Ov). (F) Pollen tubes (arrows) on the placenta surface: ovule (Ov).

\subsection{Arabinogalactan Proteins in the Placentas and Ovules after Pollination}

As was mentioned earlier, after pollination, there were both fertilized and nonfertilized ovules. In the ovules that had not been penetrated by pollen tubes, the occurrence of AGPs was similar to that in the ovules in the unpollinated flowers (Figure 6A-F). In the fertilized ovules of Utricularia nelumbifolia (after pollen tube penetration of synergid), the AGP epitopes that are recognized by JIM13, a positive signal was recoded only in a few cells of the endothelium (Figure 7A). In contrast to U. nelumbifolia, in U. humboldtii, after pollen tube penetration and fertilization, there was a strong signal in both the female gametophyte and the ovule cells (Figure 7B,C). No AGP epitopes that are recognized by 
JIM8 were observed in the fertilized ovules of $U$. nelumbifolia. In U. humboldtii, these AGPs occurred only in some of the endothelial cells and near the gametophyte (weak signal) (Figure 7D). In U. humboldtii, AGPs (labeled with JIM14) were detected in the integument cells that were located near the micropylar part of the embryo sac, the ovular chalazal cells and the placental epidermis (Figure 7E,F). After fertilization, AGPs (labeled with LM2) were detected in the placental nutritive tissue and epidermis of the placenta of Utricularia nelumbifolia (Figure 8A,B) in contrast to $U$. humboldtii, where these AGPs were not recorded (Figure 8C).

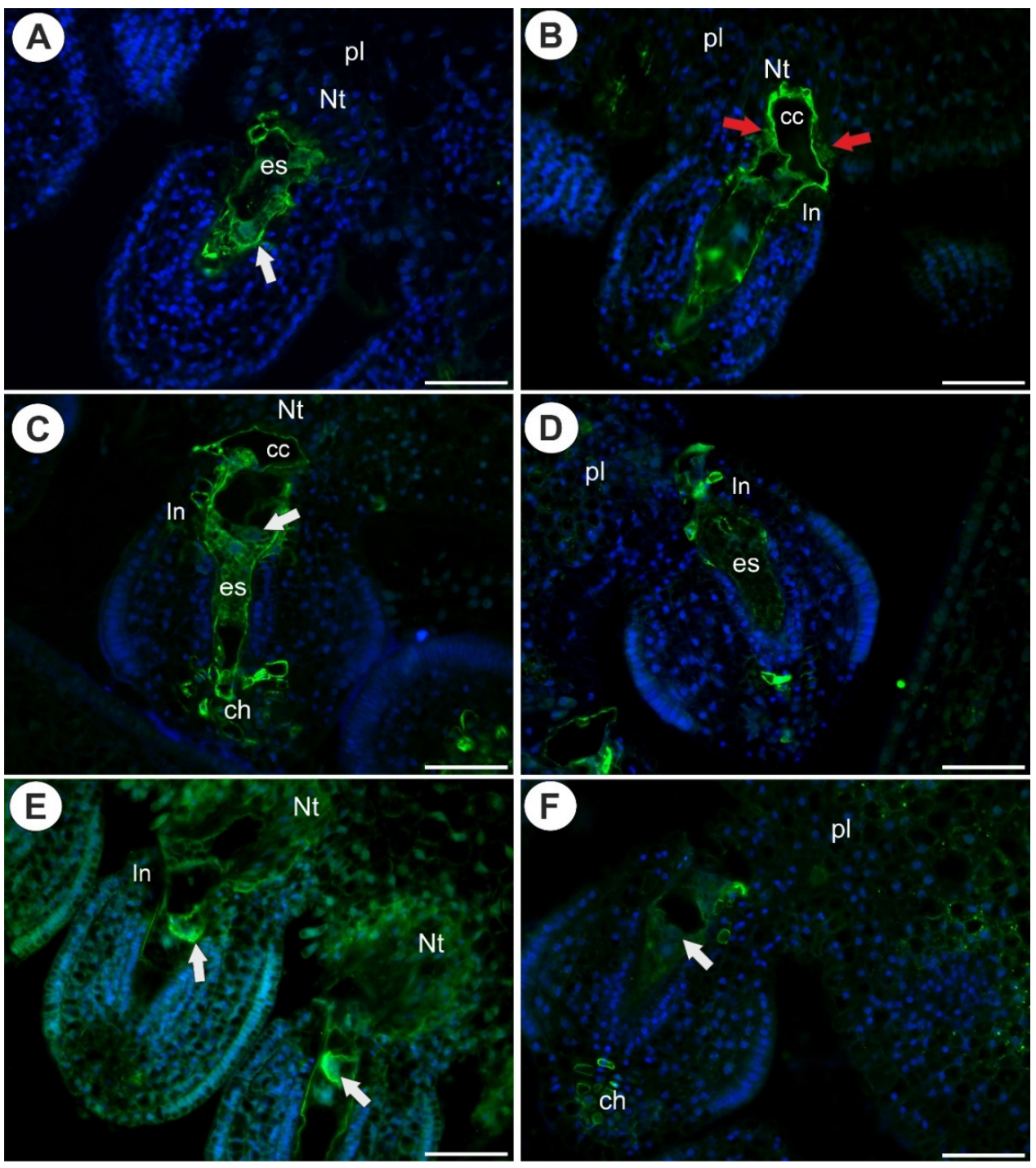

Figure 6. Arabinogalactan proteins detected in Utricularia nelumbifolia and Utricularia humboldtii after pollination but before fertilization. (A,B) Arabinogalactan protein (labeled with JIM13, green fluorescence) detected in U. nelumbifolia: placenta (pl), placenta nutritive tissue (Nt), embryo sac (es), integument (In), hypertrophied part of the central cell (cc), egg cell (white arrow), positive signal in the placenta epidermal cells (red arrows). (C) Arabinogalactan protein (labeled with JIM13, green fluorescence) detected in $U$. humboldtii: nutritive tissue (Nt), hypertrophied part of the central cell (cc), integument (In), embryo sac (es), chalaza (ch). (D) Arabinogalactan protein (labeled with JIM8, green fluorescence) detected in U. humboldtii: integument (In), placenta (pl), embryo sac (es). (E) Arabinogalactan protein (labeled with JIM14) detected in U. nelumbifolia: integument (In), nutritive tissue (Nt), egg cell (white arrow). (F) Arabinogalactan protein (labeled with JIM14, green fluorescence) detected in U. humboldtii: placenta (pl), chalaza (ch), egg cell (white arrow). All bars $50 \mu \mathrm{m}$. 

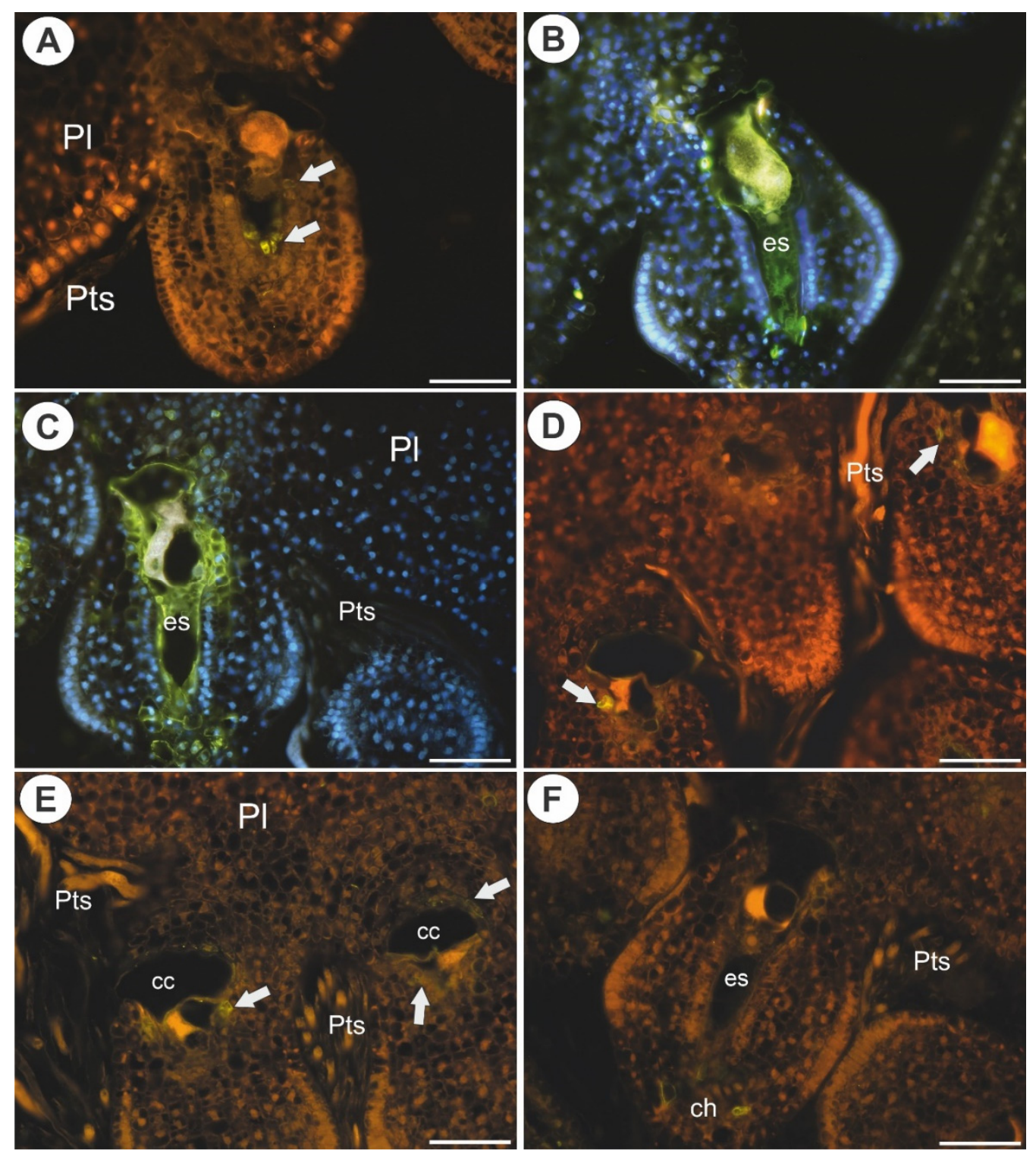

Figure 7. Arabinogalactan proteins detected in Utricularia nelumbifolia and Utricularia humboldtii after fertilization. (A,B) Arabinogalactan protein (labeled with JIM13, green fluorescence) detected in $U$. nelumbifolia: placenta (pl), positive signal in the integument cells (arrows), pollen tubes (Pts); yellowish signal is autofluorescence. (B,C) Arabinogalactan protein (labeled with JIM13, green fluorescence) detected in U. humboldtii: embryo sac (es), pollen tubes (Pts), placenta (pl). (D) Arabinogalactan protein (labeled with JIM8, green fluorescence) detected in $U$. humboldtii: positive signal in the integument cells (arrows), pollen tubes (Pts); yellowish signal is autofluorescence. (E,F) Arabinogalactan protein (labeled with JIM14, green fluorescence) detected in $U$. humboldtii, note the positive signal in the integument cells (arrows) and chalaza (ch), pollen tubes (Pts), embryo sac (es), hypertrophied part of the central cell (cc), placenta (pl); yellowish signal is autofluorescence. All bars $50 \mu \mathrm{m}$. 

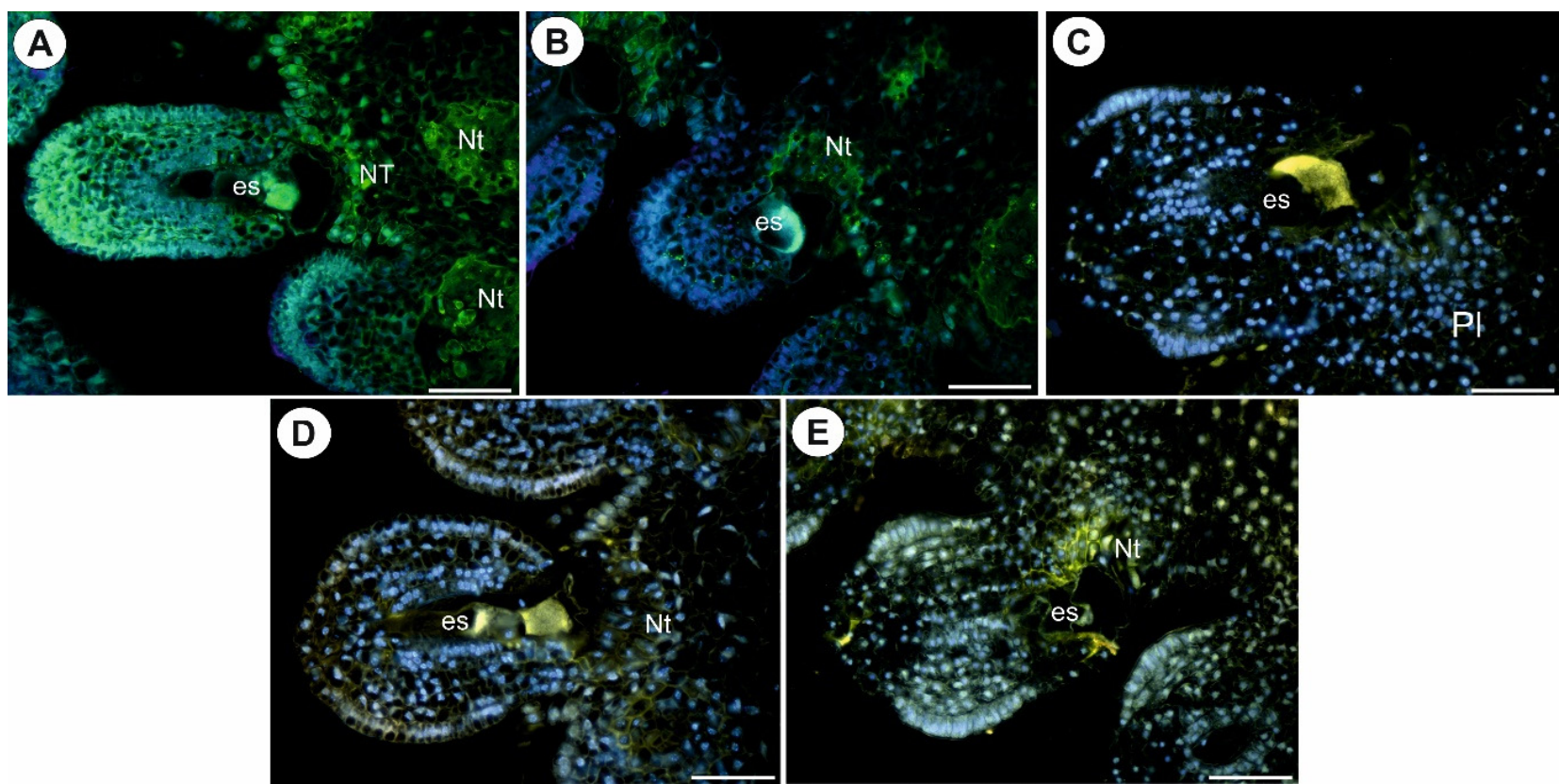

Figure 8. Arabinogalactan proteins (labeled with LM2) detected in Utricularia nelumbifolia and Utricularia humboldtii after fertilization. Control reactions of the immunolabeling of cell wall components. (A,B) Arabinogalactan proteins (labeled with LM2) detected in U. nelumbifolia; embryo sac (es), nutritive tissue (Nt). (C) Arabinogalactan proteins (labeled with LM2) detected in U. humboldtii, note no positive signal; embryo sac (es), placenta (Pl); yellowish signal is autofluorescence. (D) Ovule of U. nelumbifolia; embryo sac (es), nutritive tissue (Nt); yellowish signal is autofluorescence. (E) Ovule of U. humboldtii; embryo sac (es), nutritive tissue (Nt); yellowish signal is autofluorescence. All bars $50 \mu \mathrm{m}$.

\section{Discussion}

\subsection{Occurrence of AGPs before Pollination}

Recently, Lora et al. [7] showed that in Annona cherimola Mill. and Arabidopsis thaliana (L.) Heynh. AGPs occurred in the ovules of both unpollinated and pollinated flowers. Moreover in other angiosperm species, such as Actinidia deliciosa (A.Chev.) C.F.Liang and A.R.Ferguson, Amaranthus hypochondriacus L. [30], Olea europaea L. [39], Taraxacum officinale F.H. Wigg. [32,33], Quercus suber L. [40], Fragaria $\times$ ananassa Duchesne [41] and Pilosella officinarum Vaill. [33], AGPs are produced in the ovule before the pollen tube arrives. However, in other species, the production of AGPs is dependent on pollination and pollen tube growth [7]. We showed that in both examined Utricularia species, AGPs were produced in the ovule and placental tissues in the unpollinated flowers, which means that it is not dependent on pollination. When the development of the embryo sac was arrested, AGPs were still produced in the nucellus and integument. Thus, the production of AGPs in sporophytic tissues was not dependent on the occurrence of a mature gametophyte. This result is in contrast to the observation in Galanthus nivalis L. that was made by Chudzik et al. [33]. These authors did not find AGPs (labeled by JIM13 and JIM8) in the sterile ovules. Thus, the gametophytic control of the sporophytic tissues may differ from species to species, and in some species, the occurrence of a mature female gametophyte triggers the sporophytic tissues to produce AGPs.

In $U$. humboldtii, an intense accumulation of AGPs (labeled with JIM13) was detected in the chalaza cells. These cells organize the hypostase, which is similar to the hypostase of Torenia fournieri [42]. Pereira et al. [43] also found AGPs in the chalazal cells of Arabidopsis thaliana ovules.

The AGPs that are labeled by JIM13 and JIM8 are markers for gametophyte cell differentiation [31] and are the most common AGPs that have been reported in female gametophytes by various researchers [28]. Here, we show that in Utricularia, AGPs occurred in the egg apparatus and central cell before pollination. Similar results are 
known for various species, e.g., Amaranthus hypochondriacus [30], Arabidopsis thaliana [31], Sida hermaphrodita (L.) Rusby [44], Pitcairnia encholirioides L.B.Sm. [45], Quercus suber [46], Fragaria x ananassa [41] and Annona cherimola [7]. There are species-specific differences in AGPs. For example, we noted AGPs that are labeled by LM2 in the central cells, which is in contrast to Mendes et al. [45], who observed these AGPs in most cell types but not in the female gametophyte.

In Utricularia, the extra-ovular part of the central cell was rich in AGPs (labeled by JIM13). This result deserves special attention because this part of the female gametophyte is the first to meet the pollen tube.

However, there were differences between $U$. nelumbifolia and $U$. humboldtii for the occurrence of AGPs in the female gametophytes, particularly regarding the AGPs that are labeled by JIM 8 and JIM14. Perhaps, these differences are species specific, and they are related to the structure of the nutritive tissues in these species (only in $U$. nelumbifolia did the tissue contain the AGP epitopes that are recognized by LM2). This is especially important because $U$. nelumbifolia and $U$. humboldtii are not closely related, as was shown by studying the phylogeny of Orchidioides section [47]. However, more studies that include various species from the same genus are required in order to determine whether production of AGPs is species specific.

\subsection{AGPs Occurrence after Pollination and Fertilization}

Losada and Herrero [6] highlighted the problem that researchers overlook changes in AGPs of the ovules after pollen tube growth. However, Chudzik et al. [34] showed that in Galanthus nivalis, pollen tube growth is necessary for the production of AGPs in the ovules. The results of Losada and Herrero [6] for apple ovules are also quite important because these authors showed that AGPs disappeared from some of the ovule tissues following pollen tube passage. These authors also tracked how the pattern of AGP distribution changes during the early stages of the embryo.

Here, we showed that pollination (the occurrence pollen tubes on the placenta surface) did not change the distribution of AGPs in the ovules and female gametophytes in either of the examined species. However, the penetration of the embryo sac by the pollen tube and the process of fertilization changed the pattern of AGPs (labeled by JIM13 and JIM8) distribution in U. nelumbifolia dramatically. These AGPs disappeared from the female gametophytes. Additionally, the production of these AGPs was lower in the sporophytic tissues. This is in contrast to $U$. humboldtii in which AGPs occurred abundantly in both the female gametophytes and sporophytic tissues after pollen tube penetration. Thus, changes in the production of AGPs after pollen tube penetration are species specific. According to Losada and Herrero [6], the disappearance of AGPs from the ovule tissues after pollen tube passage proves that there is a pollen-ovule dialogue.

\subsection{Placental Epidermis and Nutritive Tissue as a Transmission Track for Pollen Tubes}

AGPs have been recorded in various unrelated plant species in the cells that form the transmission track for pollen tubes in the tissues of the style, obturator and nucellus e.g., [30,41,48-50]. In Utricularia, there is special tissue that is called the "nutritive tissue", "Nährgewebe" or "Drüsengewebe", that is located in the ovule and/or placenta. This tissue has contact with the embryo sac e.g., [16,51-53]. Previous authors have suggested that this nutritive tissue plays a key role in the nutrition of the female gametophyte [16,51-53]. In Utricularia nelumbifolia, this tissue is well developed, and its cells have nuclei with spindlelike tubular projections (chromatubules) [38]. However, we showed that the AGP epitopes that are recognized by LM2 and JIM14 in the cells of the nutritive tissue and by JIM13 in the epidermal cells are between the nutritive tissue and embryo sac. Therefore, we propose that this tissue may function as an obturator, i.e., it plays a role in pollen tube guidance. In Utricularia nelumbifolia and $U$. humboldtii, the pollen tubes grew on the placenta surface in order to reach the ovules. This is in agreement with the observations for other Utricularia species $[16,54,55]$. 
The occurrence of AGPs in the epidermis of the placenta of Utricularia proves that it plays an active role as transmission track for the pollen tubes.

\section{Materials and Methods}

The Utricularia nelumbifolia Gardner flowers were obtained in June 2018 and 2019 from the living collections of the Jagiellonian University Botanical Garden in Kraków (Kraków, Poland). The Utricularia humboldtii R.H.Schomb. flowers were obtained in April 2020 from the living collections of Department of Plant Ecology, University of Gdańsk (Gdańsk, Poland). The studies were conducted on the flowers during anthesis and in the pollinated flowers that were collected six and nine hours after pollination.

\section{Sample Preparation}

The information on the antibodies that were used in the study to show the distribution of cell wall components is presented in Table 1.

Table 1. Monoclonal antibodies that were used in the current study, the epitopes that they recognize and references.

\begin{tabular}{ccc}
\hline Antibody & Epitope & References \\
\hline JIM8 & Arabinogalactan & {$[56]$} \\
\hline JIM13 & Arabinogalactan/arabinogalactan protein & {$[57,58]$} \\
\hline JIM14 & Arabinogalactan/arabinogalactan protein & {$[57,58]$} \\
\hline LM2 & Arabinogalactan/arabinogalactan protein & {$[56]$} \\
\hline
\end{tabular}

The detailed procedures for observing the histological sections and performing the immunochemical analysis are described in Płachno et al. [33]. The plant material was fixed overnight at $4{ }^{\circ} \mathrm{C}$ in $8 \%(w / v)$ paraformaldehyde (PFA, Sigma-Aldrich, Sigma-Aldrich Sp. z o.o. Poznan, Poland) with $0.25 \%(v / v)$ glutaraldehyde (GA, Sigma-Aldrich, SigmaAldrich Sp. z o.o. Poznan, Poland) in a PIPES buffer (Sigma-Aldrich, Sigma-Aldrich Sp. $z$ o.o. Poznan, Poland). It was then embedded in Steedman's wax (PEG distearate and 1-hexadecanol; Sigma-Aldrich, Sigma-Aldrich Sp. z o.o. Poznan, Poland) and sectioned into $7 \mu \mathrm{m}$ sections, which were blocked with $1 \%$ BSA in a PBS buffer and incubated with the primary antibodies against arabinogalactans (JIM8, JIM13, JIM14, LM2) overnight at $4{ }^{\circ} \mathrm{C}$. All of the primary antibodies were purchased from Plant Probes, Leeds, UK and the secondary antibody goat anti-rat conjugated with FITC was purchased from Abcam (Abcam plc, registered in England and Wales with Company Number 03,509,322, Discovery Drive, Cambridge Biomedical Campus, Cambridge, CB2 OAX, UK). The chromatin in the nuclei was stained with $7 \mu \mathrm{g} \cdot \mathrm{mL}^{-1}$ DAPI (Sigma-Aldrich, Sigma-Aldrich Sp. z o.o. Poznan, Poland) and the samples were then cover-slipped using a Mowiol medium (Sigma-Aldrich, Sigma-Aldrich Sp. z o.o. Poznan, Poland). They were viewed using a Nikon Eclipse E800 microscope equipped with a B-2A filter, a GFP custom filter, a UV-2A filter and with differential interference contrast (DIC) optics. At least two different replications were performed for each species and developmental stage of the analyzed flowers and about five to ten sections were analyzed from each organ for each antibody that was used. Negative controls were created by omitting the primary antibody step, which caused no fluorescence signal in any of the control frames for any of the stained slides (Figure 8D,E). Decolorized aniline blue (DAB, C.I. 42755, Polyscience Europe GmbH, Hirschberg an der Bergstrasse, Germany) was used to detect the presence of callose in the ovules and placentas. For the SEM, the pistils were fixed in a mixture of $2.5 \%$ or $5 \%$ glutaraldehyde with $2.5 \%$ formaldehyde in a $0.05 \mathrm{M}$ cacodylate buffer (Sigma-Aldrich, Sigma-Aldrich Sp. z o.o. Poznan, Poland; $\mathrm{pH}$ 7.2) overnight, washed three times in a $0.1 \mathrm{M}$ sodium cacodylate buffer and later dehydrated and critical point dried using $\mathrm{CO}_{2}$. They were then sputter-coated with gold and examined at an accelerating voltage of $20 \mathrm{kV}$ using a Hitachi S-4700 scanning 
electron microscope (Hitachi, Tokyo, Japan), which is housed in the Institute of Geological Sciences, Jagiellonian University in Kraków, Poland.

\section{Conclusions}

1. In both of the examined species, arabinogalactan proteins (AGPs) were observed in the placenta, ovule (integument, chalaza) and female gametophyte of both pollinated and unpollinated flowers, thus the production of AGPs was not dependent on pollination; however, the production of some AGPs was lower after fertilization.

2. The production of some AGPs in the ovular tissues (nucellus, integument) was not dependent on the presence of a mature embryo sac. Thus, gametophytic control of the sporophytic tissues may differ from species to species.

3. The occurrence of AGPs in the placenta epidermis and nutritive tissue of Utricularia supports the hypothesis that they play an active role as a transmission track for pollen tubes.

4. In recent years, Utricularia has been proposed as a model to study plant genome evolution e.g., [58-61], carnivory and plant development e.g., [62-69]. Here, we showed that Utricularia can also be a useful and attractive model to study the malefemale dialogue in plants.

5. We plan to study cell wall components in ovules and placentas of other Utricularia species that have differently developed nutrient tissues and form special syncytia.

Author Contributions: B.J.P. designed the project; B.J.P., M.K. performed the analyses and data visualization; B.J.P. prepared the original manuscript draft; B.J.P., K.B. cultivated and/or collected the plants; B.J.P., M.K., V.F.O.M., A.B.-K. edited the manuscript; B.J.P., P.Ś., A.B.-K. obtained the funding. All of the authors were involved in developing the experimental concepts and also critically revised the manuscript. All authors have read and agreed to the published version of the manuscript.

Funding: The analyses were partially supported by a Fast Track Grant funded by the Faculty of Natural Sciences, University of Silesia in Katowice to P. S. This research was also partially financially supported by the Ministry of Science and Higher Education of Poland within the statutory activities of the Department of Plant Cytology and Embryology, Institute of Botany, Faculty of Biology, Jagiellonian University in Kraków (N18/DBS/000002), and the Department of Plant Cytology and Embryology, Faculty of Biology, University of Gdańsk (531-D030-D847-21) and also by Medical University of Lublin.

Institutional Review Board Statement: Not applicable.

Informed Consent Statement: Not applicable.

Data Availability Statement: Not applicable.

Conflicts of Interest: The authors declare no conflict of interest.

\section{References}

1. Bouman, F. The Ovule. In Embryology of Angiosperms; Springer Science and Business Media LLC: Berlin/Heidelberg, Germany, 1984; pp. 123-157.

2. Endress, P.K. Angiosperm ovules: Diversity, development, evolution. Ann. Bot. 2011, 107, 1465-1489. [CrossRef] [PubMed]

3. Herrero, M. Changes in the Ovary Related to Pollen Tube Guidance. Ann. Bot. 2000, 85, 79-85. [CrossRef]

4. Herrero, M. Ovary signals for directional pollen tube growth. Sex. Plant. Reprod. 2001, 14, 3-7. [CrossRef]

5. Li, H.J.; Meng, J.G.; Yang, W.C. Multilayered signaling pathways for pollen tube growth and guidance. Plant. Reprod. 2018, 31, 31-41. [CrossRef]

6. Losada, J.M.; Herrero, M. Arabinogalactan proteins mediate intercellular crosstalk in the ovule of apple flowers. Plant. Reprod. 2019, 32, 291-305. [CrossRef] [PubMed]

7. Lora, J.; Laux, T.; Hormaza, J.I. The role of the integuments in pollen tube guidance in flowering plants. New Phytol. 2018, 221, 1074-1089. [CrossRef]

8. Leslie, A.B.; Boyce, C.K. Ovule Function and the Evolution of Angiosperm Reproductive Innovations. Int. J. Plant. Sci. 2012, 173, 640-648. [CrossRef]

9. Lora, J.; Hormaza, J.I.; Herrero, M. The Diversity of the Pollen Tube Pathway in Plants: Toward an Increasing Control by the Sporophyte. Front. Plant. Sci. 2016, 7, 107. [CrossRef] 
10. Gotelli, M.M.; Lattar, E.C.; Zini, L.M.; Galati, B.G. Style morphology and pollen tube pathway. Plant. Reprod. 2017, 30, 155-170. [CrossRef] [PubMed]

11. Lora, J.; Herrero, M.; Tucker, M.R.; Hormaza, J.I. The transition from somatic to germline identity shows conserved and specialized features during angiosperm evolution. New Phytol. 2017, 216, 495-509. [CrossRef] [PubMed]

12. Bencivenga, S.; Colombo, L.; Masiero, S. Cross talk between the sporophyte and the megagametophyte during ovule development. Sex. Plant. Reprod. 2011, 24. [CrossRef]

13. Bedinger, P.A.; Broz, A.K.; Tovar-Mendez, A.; McClure, B. Pollen-Pistil Interactions and Their Role in Mate Selection. Plant. Physiol. 2017, 173, 79-90. [CrossRef] [PubMed]

14. Huang, B.Q.; Russell, S.D.; Strout, G.W.; Mao, L.J. Organization of isolated embryo sacs and eggs of Plumbago zeylanica (Plumbaginaceae) before and after fertilization. Am. J. Bot. 1990, 77, 401-1410. [CrossRef]

15. Chute, H.M.; Maheshwari, P. An Introduction to the Embryology of Angiosperms. Bull. Torrey Bot. Club 1951, 78, 272. [CrossRef]

16. Khan, R. A contribution to the embryology of Utricularia flexuosa Vahl. Phytomorphology 1954, 4, 80-117.

17. Higashiyama, T.; Inatsugi, R.; Sakamoto, S.; Sasaki, N.; Mori, T.; Kuroiwa, H.; Nakada, T.; Nozaki, H.; Kuroiwa, T.; Nakano, A. Species Preferentiality of the Pollen Tube Attractant Derived from the Synergid Cell of Torenia fournieri. Plant. Physiol. 2006, 142, 481-491. [CrossRef]

18. Płachno, B.J. Female germ unit in Genlisea and Utricularia, with remarks about the evolution of the extra-ovular female gametophyte in members of Lentibulariaceae. Protoplasma 2011, 248, 391-404. [CrossRef] [PubMed]

19. Higashiyama, T.; Kuroiwa, H.; Kawano, S.; Kuroiwa, T. Kinetics of double fertilization in Torenia fournieri based on direct observations of the naked embryo sac. Planta 1997, 203, 101-110. [CrossRef]

20. Higashiyama, T.; Yang, W.-C. Gametophytic Pollen Tube Guidance: Attractant Peptides, Gametic Controls, and Receptors. Plant. Physiol. 2017, 173, 112-121. [CrossRef]

21. Higashiyama, T.; Kuroiwa, H.; Kawano, S.; Kuroiwa, T. Guidance in Vitro of the Pollen Tube to the Naked Embryo Sac of Torenia fournieri. Plant. Cell 1998, 10, 2019-2031. [CrossRef] [PubMed]

22. Higashiyama, T.; Yabe, S.; Sasaki, N.; Nishimura, Y.; Miyagishima, S.; Kuroiwa, H.; Kuroiwa, T. Pollen tube attraction by the synergid cell. Science 2001, 293, 1480-1483. [CrossRef]

23. Higashiyama, T.; Kuroiwa, H.; Kuroiwa, T. Pollen-tube guidance: Beacons from the female gametophyte. Curr. Opin. Plant. Biol. 2003, 6, 36-41. [CrossRef]

24. Okuda, S.; Tsutsui, H.; Shiina, K.; Sprunck, S.; Takeuchi, H.; Yui, R.; Kasahara, R.D.; Hamamura, Y.; Mizukami, A.; Susaki, D.; et al. Defensin-like polypeptide LUREs are pollen tube attractants secreted from synergid cells. Nat. Cell Biol. 2009, 458, 357-361. [CrossRef] [PubMed]

25. Mizukami, A.G.; Inatsugi, R.; Jiao, J.; Kotake, T.; Kuwata, K.; Ootani, K.; Okuda, S.; Sankaranarayanan, S.; Sato, Y.; Maruyama, D.; et al. The AMOR Arabinogalactan Sugar Chain Induces Pollen-Tube Competency to Respond to Ovular Guidance. Curr. Biol. 2016, 26, 1091-1097. [CrossRef]

26. Pereira, A.M.; Lopes, A.L.; Coimbra, S. Arabinogalactan Proteins as Interactors along the Crosstalk between the Pollen Tube and the Female Tissues. Front. Plant. Sci. 2016, 7, 1895. [CrossRef]

27. Su, S.; Higashiyama, T. Arabinogalactan proteins and their sugar chains: Functions in plant reproduction, research methods, and biosynthesis. Plant. Reprod. 2018, 31, 67-75. [CrossRef] [PubMed]

28. Leszczuk, A.; Szczuka, E.; Zdunek, A. Arabinogalactan proteins: Distribution during the development of male and female gametophytes. Plant. Physiol. Biochem. 2019, 135, 9-18. [CrossRef]

29. Showalter, A.M. Arabinogalactan-proteins: Structure, expression and function. Cell. Mol. Life Sci. 2001, 58, 1399-1417. [CrossRef]

30. Coimbra, S.; Duarte, C. Arabinogalactan proteins may facilitate the movement of pollen tubes from the stigma to the ovules in Actinidia deliciosa and Amaranthus hypochondriacus. Euphytica 2003, 133, 171-178. [CrossRef]

31. Coimbra, S.; Almeida, J.; Junqueira, V.; Costa, M.L.; Pereira, L.G. Arabinogalactan proteins as molecular markers in Arabidopsis thaliana sexual reproduction. J. Exp. Bot. 2007, 58, 4027-4035. [CrossRef]

32. Gawecki, R.; Sala, K.; Kurczyńska, E.U.; Świątek, P.; Płachno, B.J. Immunodetection of some pectic, arabinogalactan proteins and hemicellulose epitopes in the micropylar transmitting tissue of apomictic dandelions (Taraxacum, Asteraceae, Lactuceae). Protoplasma 2017, 254, 657-668. [CrossRef]

33. Płachno, B.J.; Kapusta, M.; Świątek, P.; Stolarczyk, P.; Kocki, J. Immunodetection of Pectic Epitopes, Arabinogalactan Proteins, and Extensins in Mucilage Cells from the Ovules of Pilosella officinarum Vaill. and Taraxacum officinale agg. (Asteraceae). Int. J. Mol. Sci. 2020, 21, 9642. [CrossRef]

34. Chudzik, B.; Koscinska-Pajak, M.; Snieżko, R. Immunodetection of arabinogalactan proteins (AGPs) in apomictic ovules of Chondrilla juncea L. Acta Biol. Crac. Ser. Bot. 2005, 47, 35.

35. Płachno, B.J.; Świątek, P. Actin cytoskeleton in the extra-ovular embryo sac of Utricularia nelumbifolia (Lentibulariaceae). Protoplasma 2012, 249, 663-670. [CrossRef]

36. Khan, R. Lentibulariaceae. Bull. Indian Nat. Sci. Acad. 1970, 41, 290-297.

37. Lora, J.; Perez, V.; Herrero, M.; Hormaza, J.I. Ovary Signals for Pollen Tube Guidance in Chalazogamous Mangifera indica L. Front. Plant. Sci. 2021, 11, 601706. [CrossRef]

38. Płachno, B.J.; Świątek, P.; Jobson, R.W.; Małota, K.; Brutkowski, W. Serial block face SEM visualization of unusual plant nuclear tubular extensions in a carnivorous plant (Utricularia, Lentibulariaceae). Ann. Bot. 2017, 120, 673-680. [CrossRef] 
39. Suárez, C.; Zienkiewicz, A.; Castro, A.J.; Zienkiewicz, K.; Majewska-Sawka, A.; Rodríguez-García, M.I. Cellular localization and levels of pectins and arabinogalactan proteins in olive (Olea europaea L.) pistil tissues during development: Implications for pollen-pistil interaction. Planta 2013, 237, 305-319. [CrossRef]

40. da Costa, M.L.; Lopes, A.L.; Amorim, M.I.; Coimbra, S. Immunolocalization of AGPs and Pectins in Quercus suber Gametophytic Structures. Methods Mol. Biol. 2017, 1669, 117-137.

41. Leszczuk, A.; Szczuka, E. Arabinogalactan proteins: Immunolocalization in the developing ovary of a facultative apomict Fragaria $\mathrm{x}$ ananassa (Duch.). Plant. Physiol. Biochem. 2018, 123, 24-33. [CrossRef] [PubMed]

42. Tiwari, S.C. The Hypostase in Torenia fournieri Lind.: A Histochemical Study of the Cell Walls. Ann. Bot. 1983, 51, 17-26. [CrossRef]

43. Pereira, A.M.; Masiero, S.; Nobre, M.S.; Costa, M.L.; Solís, M.-T.; Testillano, P.S.; Sprunck, S.; Coimbra, S. Differential ex-pression patterns of arabinogalactan proteins in Arabidopsis thaliana reproductive tissues. J. Exp. Bot. 2014, 65, 5459-5471. [CrossRef]

44. Chudzik, B.; Burlik, M.; Zarzyka, B.; Szczuka, E. Localization of arabinogalactan proteins during development of gametophytes in Bellis perennis L. Acta Biol. Cracov. Bot. 2010, 52, 52.

45. Mendes, S.P.; Mastroberti, A.A.; Mariath, J.E.; Vieira, R.C.; De Toni, K.L. Ovule and female gametophyte development in the Bromeliaceae: An embryological study of Pitcairnia encholirioides. Bots 2014, 92, 883-894. [CrossRef]

46. Lopes, A.; Costa, M.; Sobral, R.; Costa, M.M.; Amorim, M.I.; Coimbra, S. Arabinogalactan proteins and pectin distribution during female gametogenesis in Quercus suber L. Ann. Bot. 2016, 117, 949-961. [CrossRef] [PubMed]

47. Rodrigues, F.G.; Marulanda, N.F.; Silva, S.R.; Płachno, B.J.; Adamec, L.; Miranda, V.F.O. Phylogeny of the 'orchid-like' bladderworts (gen. Utricularia sect. Orchidioides and Iperua: Lentibulariaceae) with remarks on the stolon-tuber system. Ann. Bot. 2017, 120, 709-723. [CrossRef]

48. Lora, J.; Hormaza, J.I. Pollen wall development in mango (Mangifera indica L.; Anacardiaceae). Plant. Reprod. 2018, 31, 385-397. [CrossRef]

49. Coimbra, S.; Jones, B.; Pereira, L.G. Arabinogalactan proteins (AGPs) related to pollen tube guidance into the embryo sac in Arabidopsis. Plant. Signal. Behav. 2008, 3, 455-456. [CrossRef]

50. Losada, J.M.; Herrero, M. Pollen tube access to the ovule is mediated by glycoprotein secretion on the obturator of apple (Malus $\mathrm{x}$ domestica, Borkh). Ann. Bot. 2017, 119, 989-1000. [CrossRef]

51. Merz, M. Untersuchungen über die Samenentwicklung der Utricularien. Flora 1897, 84, 69-87.

52. Merl, E.H. Beiträge zur Kenntnis der Utricularien und Genlisen. Flora 1915, 108, 127-200.

53. Płachno, B.J.; Świątek, P. Cytoarchitecture of Utricularia nutritive tissue. Protoplasma 2008, 234, 25-32. [CrossRef] [PubMed]

54. Farooq, M. Studies in the Lentibulariaceae the embryology of U. stellaris Linn. f. var. inflexa. Part II. Microsporangium, male gametophyte, fertilization, endosperm, embryo and seed. Proc. Natl. Inst. Sci. India 1964, 30, 280-290.

55. Siddiqui, S.A. Studies in the Lentibulariaceae Pollination, fertilisation, endosperm, embryo and seed in U. dichotoma Labill. Bot. Jahrb. Syst. 1978, 100, 237-245.

56. Pennell, R.I.; Janniche, L.; Kjellbom, P.; Scofield, G.N.; Peart, J.M.; Roberts, K. Developmental regulation of a plasma membrane arabinogalactan protein epitope in oilseed rape flowers. Plant. Cell 1991, 3, 1317-1326. [CrossRef] [PubMed]

57. Yates, E.A.; Valdor, J.-F.; Haslam, S.M.; Morris, H.R.; Dell, A.; Mackie, W.; Knox, J. Characterization of carbohydrate structural features recognized by anti-arabinogalactan-protein monoclonal antibodies. Glycobiology 1996, 6, 131-139. [CrossRef] [PubMed]

58. Lan, T.; Renner, T.; Ibarra-Laclette, E.; Farr, K.M.; Chang, T.-H.; Cervantes-Pérez, S.A.; Zheng, C.; Sankoff, D.; Tang, H.; Purbojati, R.W.; et al. Long-read sequencing uncovers the adaptive topography of a carnivorous plant genome. Proc. Natl. Acad. Sci. USA 2017, 114, E4435-E4441. [CrossRef] [PubMed]

59. Silva, S.R.; Pinheiro, D.G.; Penha, H.A.; Płachno, B.J.; Michael, T.P.; Meer, E.J.; Miranda, V.F.O.; Varani, A.M. Intraspecific Variation within the Utricularia amethystina Species Morphotypes Based on Chloroplast Genomes. Int. J. Mol. Sci. 2019, 20, 6130. [CrossRef] [PubMed]

60. Silva, S.R.; Moraes, A.P.; Penha, H.A.; Julião, M.H.M.; Domingues, D.S.; Michael, T.P.; Miranda, V.F.O.; Varani, A.M. The Terrestrial Carnivorous Plant Utricularia reniformis Sheds Light on Environmental and Life-Form Genome Plasticity. Int. J. Mol. Sci. 2019, 21, 3. [CrossRef]

61. Ibarra-Laclette, E.; Lyons, E.; Hernández-Guzmán, G.; Pérez-Torres, C.A.; Carretero-Paulet, L.; Chang, T.-H.; Lan, T.; Welch, A.J.; Juárez, M.J.A.; Simpson, J.; et al. Architecture and evolution of a minute plant genome. Nature 2013, 498, 94-98. [CrossRef]

62. Poppinga, S.; Weisskopf, C.; Westermeier, A.S.; Masselter, T.; Speck, T. Fastest predators in the plant kingdom: Functional morphology and biomechanics of suction traps found in the largest genus of carnivorous plants. AoB Plants 2016, 8, 140. [CrossRef] [PubMed]

63. Płachno, B.J.; Świątek, P.; Miranda, V.F.O.; Stolarczyk, P. The Structure and Occurrence of a Velum in Utricularia Traps (Lentibulariaceae). Front. Plant. Sci. 2019, 10, 302. [CrossRef] [PubMed]

64. Płachno, B.J.; Świątek, P.; Adamec, L.; Carvalho, S.; Miranda, V.F.O. The Trap Architecture of Utricularia multifida and Utricularia westonii (subg. Polypompholyx). Front. Plant. Sci. 2019, 10, 336. [CrossRef] [PubMed]

65. Lee, K.J.I.; Bushell, C.; Koide, Y.; Fozard, J.A.; Piao, C.; Yu, M.; Newman, J.; Whitewoods, C.; Avondo, J.; Kennaway, R.; et al. Shaping of a three-dimensional carnivorous trap through modulation of a planar growth mechanism. PLoS Biol. 2019, 17, e3000427. [CrossRef] [PubMed]

66. Whitewoods, C.D.; Gonçalves, B.; Cheng, J.; Cui, M.; Kennaway, R.; Lee, K.; Bushell, C.; Yu, M.; Piao, C.; Coen, E. Evolution of carnivorous traps from planar leaves through simple shifts in gene expression. Science 2020, 367, 91-96. [CrossRef] 
67. Whitewoods, C.D.; Coen, E. Growth and Development of Three-Dimensional Plant Form. Curr. Biol. 2017, 27, R910-R918. [CrossRef]

68. Rutishauser, R. EvoDevo: Past and Future of Continuum and Process Plant Morphology. Philosophy 2020, 5, 41. [CrossRef]

69. Reut, M.S.; Płachno, B.J. Unusual developmental morphology and anatomy of vegetative organs in Utricularia dichotoma-Leaf, shoot and root dynamics. Protoplasma 2020, 257, 371-390. [CrossRef] [PubMed] 